\title{
Spatial variability of available water and micro-sprinkler irrigation in cambisol ${ }^{1}$
}

\author{
Larissa Luana Nicodemos Ferreira ${ }^{2 *}$, Luis César de Aquino Lemos Filho ${ }^{2}$, Marcílio Macêdo Torres ${ }^{2}$, Raimundo \\ Fernandes de Oliveira Júnior ${ }^{2}$, Clara Nívea Costa do Vale ${ }^{2}$, Mariuchy Sammara de Brito Paiva Franco ${ }^{2}$
}

$10.1590 / 0034-737 X 201663060006$

\begin{abstract}
The technology of irrigation is vital for agricultural production. Thus, description of spatial patterns of both water application and available water capacity in the soil, as well as their interactions, is essential to maximize efficiency of water use in irrigated areas. The objective of this study was to analyze spatial variability of available water capacity in the soil and water application via irrigation using geostatistics. The experiment was conducted in a commercial mango orchard in Cambisol irrigated by micro sprinkler system, in the municipality of Alto do Rodrigues, RN. Analyses of descriptive statistics and geostatistics were performed using the programs GeoR and GS+. Geostatistics was found suitable for describing the structure of spatial dependence of available water capacity in the soil and the flow rate distributed in the area by sprinklers. Moreover, even with good results for Christiansen Uniformity Coefficient (CU) and Distribution Uniformity Coefficient (DU), the area showed spatial variability of flow rate.
\end{abstract}

Key words: soil properties; geostatistics; microirrigation.

\section{RESUMO}

\section{Variabilidade espacial de água disponível e da aplicação de água em cambissolo por microaspersão}

A tecnologia da irrigação é fundamental para produção agrícola. Logo, as descrições dos padrões espaciais da aplicação de água e da capacidade de água disponível no solo, além de suas interações, são fundamentais para racionalizar o uso da água em áreas irrigadas. Assim, este estudo propõe analisar, por meio de técnicas geoestatísticas, a variabilidade espacial da capacidade de água disponível no solo e da aplicação de água via irrigação. O experimento foi conduzido numa área comercial de produção de manga, sob Cambissolo irrigado por microaspersão, no município do Alto do Rodrigues, RN. As análises de estatística descritiva e geoestatística foram realizadas pelos softwares GeoR e GS+. Os resultados indicaram que a geoestatística foi adequada para descrever a estrutura de dependência espacial da capacidade de água disponível no solo e da vazão distribuída na área pelos emissores de irrigação, e que, mesmo com bons resultados de Coeficiente de Uniformidade de Christiansen e Coeficiente de Uniformidade de Distribuição, a área apresentou variabilidade espacial da vazão aplicada.

Palavras-chave: atributos do solo; geoestatística; irrigação localizada.

\footnotetext{
Submitted on April 1st, 2014 and accepted on August 11 $1{ }^{\text {th }}, 2016$.

${ }^{1}$ This work is part of the first author's dissertation..

${ }^{2}$ Universidade Federal Rural do Semi-Árido, Departamento de Ciências Ambientais e Tecnológicas, Mossoró, Rio Grande do Norte, Brazil. larissa.nic@ hotmail.com; lcalfilho@ufersa.edu.br; marcilioagro@yahoo.com.br; junior182@outlook.com; claranivea@hotmail.com; mariuchy_sammara@ hotmail.com

*Corresponding author: larissa.nic@hotmail.com
}

Rev. Ceres, Viçosa, v. 63, n.6, p. 782-788, nov/dez, 2016 


\section{INTRODUCTION}

Water is the most important natural resource as it is essential in all aspects of life, including food production, and the proper management of water supply can result in large economy of water and energy and great improvements in agricultural production (Coelho et al., 2005). Irrigation provides adequate water for plant growth, so plants can express all their genetic potential. However, irrigation generally results in excessive application of water in some areas of planting and insufficient water in others because of the natural non-uniformity of the cultivated areas (Lemos Filho, 2010).

Therefore, well designed irrigation systems, with good uniformity of water application and proper irrigation management, provide higher yield, reduce water loss (Prado \& Colombo 2011; Oliveira et al., 2012) and leaching (Agostinho, 2011), and maximize available water resources (Santos et al., 2013). For this reason, we need the right combination of the several factors which enable the quantification of water to be applied in each irrigation.

According to Cunha et al. (2008), uniformity of application affects crop yields and is vital for the economy of the project in any irrigation system. Frizzone et al. (2007) emphasized that the uniformity of water content in the soil profile and yield of irrigated crops are highly dependent on the uniformity of water application.

Merriam \& Keller (1978) proposed the following classification for the coefficients of uniformity of water application:

Values are $90 \%$ or greater, excellent; $80-90 \%$, good; 70 $80 \%$, fair; less than $70 \%$, poor.

A number of studies, including Lima et al. (2015) and Araújo et al. (2014) reported that the variability of physical and hydraulic properties of the soil shows correlation or spatial dependence. Because of this, several geostatistical tools are used to study the spatial variability of soil attributes and can potentially lead to management practices that allow a better understanding of the interaction between the soil-plant-atmosphere system (Lemos Filho, 2010).

Thus, analysis of soil variability using geostatistical techniques may indicate management alternatives to reduce the effects of soil variability on crop production, aiming at maximizing yield potential (Vian et al., 2016). That is, the mapping of the spatial variability of physical and hydraulic soil properties allows the differentiated application of water by management areas, favoring yield optimization, increasing input efficiency, maximizing benefits and reducing costs. Thus, this study aims to analyze the spatial variability of available water capacity in the soil and water application via irrigation using geostatistics.

\section{MATERIAL AND METHODS}

The experiment was conducted in a commercial mango (Mangifera indica L.) orchard in Cambisol (Embrapa, 2006) located in the Irrigated Perimeter Osvaldo Amorim, Vale do Açu, municipality of Alto Rodrigues-RN, UTM (Universal Transverse Mercator System) coordinates in SAD69 Datum 9404004 latitude and 745308 longitude, $48 \mathrm{~m}$ average altitude. The climate is BSwh type, according to the Köppen climate classification (Carmo Filho et al., 1991), dry, with annual potential evapotranspiration higher than the annual rainfall, with average annual rainfall between 380 and $760 \mathrm{~mm}$ and an average temperature of $27.4^{\circ} \mathrm{C}$.

Considering the border effect, a $100 \mathrm{~m}$ x $64 \mathrm{~m}$ rectangular grid was laid out with at least two rows of plants bordering the experiment, totaling 133 plants. Sampling was carried out in alternating rows, as well as plants of each row selected, so that the sample points were spaced $16 \mathrm{~m} \times 10$ $\mathrm{m}$, totaling 40 points.

The experimental area has a micro-sprinkler irrigation system. Rotating micro-sprinklers were used with flow rate of $50 \mathrm{~L} \mathrm{~h}^{-1}$ and operating pressure of $200 \mathrm{kPa}$, spaced $8 \mathrm{~m}$ between rows and $5 \mathrm{~m}$ between plants. The water used in the irrigation was raised from the Piranhas River, transported by canals, pressurized in a pumping substation, and reached the plot with $350 \mathrm{kPa}$ of pressure. During the evaluation of the irrigation system, the flow rate of the emitters was measured twice on different dates, with three replications for each test of the irrigation system as described by Bernardo et al. (2011).

Uniformity of irrigation application was determined according to the methodology proposed by Keller \& Karmeli (1975) and Christiansen (1942).

For the characterization of physical and hydraulic soil properties of the area in study, both undisturbed (Uhland sampler) and disturbed soil samples were collected at 0.3 $\mathrm{m}$ depth (soil profile of $0-0.3 \mathrm{~m}$ ) at each sampling point, depending on the crop spacing, totaling 40 sampling points and 80 soil samples collected. The soil samples were used for determining: soil density, particle density, texture, water retention curves in soil and water holding capacity according to Donagema (2011). For determination of the characteristic curves, tensions of 10,33, 100, 500 and 1500 $\mathrm{kPa}$ were applied. All (forty) water-soil retention curves were adjusted by the mathematical model proposed by Van Genuchten (1980) with the software developed by Dourado Neto et al. (2001).

Descriptive statistical analysis and exploratory data analysis were performed to visualize the general behavior and identify possible outlier values, without considering the geographical position of the observed data. The fitting of experimental data was obtained using the spherical, exponential and Gaussian mathematical models, and the 
model parameters nugget effect, sill and range were estimated.

To select the best model to fit the semivariogram into the experimental data, the criteria established were the highest coefficient of determination $\left(\mathrm{R}^{2}\right)$ and the degree of spatial dependence defined by Cambardella et al. (1994). Data were georeferenced in metric coordinates and a matrix system that allows applications with minimal area deformation.

The analysis of descriptive statistics and geostatistics for all variables were performed using the software Statistica Development Environment, GS+ (Gamma Design Software, 2004) and GeoR (Ribeiro Júnior \& Diggle, 2001). After the exploratory analyzes, the experimental semivariograms were built and the theoretical semivariograms for the spherical, exponential and Gaussian models were fitted.

Later, all the parameters required for kriging interpolation of the results were selected. The ratios between the nugget effect and sill $\left(\mathrm{C}_{0} / \mathrm{C}_{0}+\mathrm{C}_{1}\right)$ were calculated for each fitted model. This ratio, according Cambardella et al. (1994) measures the degree of spatial dependence of the sampled attribute.

Contour maps were constructed for the attributes that had spatial dependence, using geostatistical Kriging interpolation (Vieira, 2000).

\section{RESULTS AND DISCUSSION}

Table 1 shows the Christiansen Uniformity Coefficients (CUC) and the Distribution Uniformity Coefficients (DUC) for the two measurements of water distribution uniformity. The CUC values show that the irrigation system had excellent application uniformity, according to Mantovani (2000) and Pereira (2001).

However, following the classification of Merriam \& Keller (1978), DCU was considered good. Still, according to these authors, for micro-sprinkler irrigation, only below $70 \%$, DCU is considered poor or unacceptable.
Table 2 shows the descriptive statistics for flow rate $(\mathrm{L}$ $\mathrm{h}^{-1}$ ) measured in February and March 2012. The average flow rate of emitters were 49.62 and $47.77 \mathrm{~L} \mathrm{~h}^{-1}$ (ranging from $37.20 ; 37.40$; to $82.36 ; 84.56 \mathrm{~L} \mathrm{~h}^{-1}$ ) for each measurement, respectively. The coefficients of variation for the two measurements were 16.02 and $15.57 \%$, respectively, which were classified as very good uniformity according to Bralts \& Kesner (1983) and confirmed by the CUC and DCU values.

Table 3 shows the results of the geostatistical analysis for flow rate $\left(\mathrm{L} \mathrm{h}^{-1}\right)$ of the two measurements. The scale of spatial dependence proposed by Cambardella et al. (1994) was used in the analyses of the semivariograms showing that there is strong spatial dependence in the three models because the nugget effects $\left(\mathrm{C}_{0}\right)$ were lower than the sill (GD $<25 \%$ ). Table 3 also shows that the exponential model had the highest spatial dependence. However, the spherical model stood out for both the coefficients of determination $\left(\mathrm{R}^{2}\right)$ and the degree of spatial dependence.

The maps in Figures 1 and 2 show the flow rate $\left(\mathrm{L} \mathrm{h}^{-1}\right)$ by kriging spatialization for the two measurements. The maps indicate that the irrigation system of the experimental area had a spatial distribution of flow rate similar in the measurements made on the different dates, showing temporal stability of the spatial variation in the flow rate. However, there is large spatial variation in the flow rate within the area. This can damage crop development, since some plants may receive excess water and others insufficient water. Another important observation is that there is a concentration of high flow rates in the center of the area.

Table 4 shows the descriptive statistics for data on texture and soil density determined for the 40 sampling points in the soil of the studied area (0-0.3 m deep).

According to the classification criteria proposed by Warrick \& Nielsen (1980) for the coefficient of variation (CV), indicating variability around the mean, the $\mathrm{CV}$ values found for dispersion were moderate for the variables silt (24.23\%) and clay (25.40\%), and low for the

Table 1: Percentage values of Christiansen Uniformity Coefficient (CUC) and Distribution Uniformity Coefficient (DUC)

\begin{tabular}{lccccc}
\hline \multirow{2}{*}{ Date } & \multicolumn{3}{c}{ CUC } & & \multicolumn{2}{c}{ DCU } \\
\cline { 2 - 3 } \cline { 6 - 6 } & Value (\%) & Classification* & & Value (\%) & Classification** \\
\hline February & 89.29 & Excellent & & 85.14 & Good \\
March & 89.79 & Excellent & & 86.70 & Good \\
\hline
\end{tabular}

*Classification by Mantovani (2000) and Pereira (2001). **Classification by Merriam and Keller (1978).

Table 2: Descriptive statistics for flow rate $\left(\mathrm{L} \mathrm{h}^{-1}\right)$

\begin{tabular}{lcccccccc}
\hline Measurement & $\boldsymbol{\mu}\left(\mathbf{L} \mathbf{h}^{-1}\right)$ & $\boldsymbol{\eta}\left(\mathbf{L} \mathbf{h}^{-\mathbf{1}}\right)$ & $\mathbf{Q}_{\max }\left(\mathbf{L} \mathbf{h}^{-\mathbf{1}}\right)$ & $\mathbf{Q}_{\operatorname{mim}}\left(\mathbf{L} \mathbf{h}^{-\mathbf{1}}\right)$ & $\boldsymbol{\sigma}$ & $\mathbf{C V}(\boldsymbol{\%})$ & $\mathbf{S k e}$ & $\mathbf{K u r}$ \\
\hline February & 49.62 & 48.08 & 84.56 & 37.20 & 7.95 & 16.02 & 2.24 & 8.67 \\
March & 47.77 & 46.34 & 82.36 & 37.40 & 7.44 & 15.57 & 2.72 & 11.32 \\
\hline
\end{tabular}

Mean $(\mu)$, median $(\eta)$, maximum and minimum flow rate (Qmax and Qmin), standard deviation $(\sigma)$, coefficient of variation $(\mathrm{CV})$, skewness (Ske) and kurtosis (Kur).

Rev. Ceres, Viçosa, v. 63, n.6, p. 782-788, nov/dez, 2016 
variables sand (7.95\%), bulk density (5.44\%), and particle density $(1.27 \%)$. The properties sand, bulk density and particle density were classified as low variability, not exceeding $10 \%$. The clay content showed a CV much higher than the sand content, corroborating the findings of Nielsen et al., (1973), as well as similar to the results found by Lima et al. (2006).

Table 5 shows the descriptive statistics for volumetric soil moisture at field capacity $\left(\theta_{\mathrm{Fc}}\right)$, volumetric permanent wilting point $\left(\theta_{\mathrm{PWP}}\right)$, and soil available water capacity (AWC, $\mathrm{mm})$. Note that the mean AWC $(\mu)$ in the area over the period was $74.29 \mathrm{~mm}$ (ranging from $42.42 \mathrm{~mm}$ to $104.55 \mathrm{~mm}$ ). There is also symmetry in the distribution of the data, because of the similarity between the values of measures of position (mean and median), with the distribution being close to the normal distribution, showing symmetrical distributions, which can be confirmed by the values of asymmetry near zero.

The coefficient of variation (CV) was $17.78 \%$ and according to the classification proposed by Wilding \& Drees (1983), this CV for AWC (mm) can be considered of moderate variability. Values of standard deviation and coefficient of variation give idea of the magnitude of variability of the soil properties analyzed, but inform us nothing of the spatial dependence structure of AWC, which is only possible using geostatistical techniques.

Table 3: Nugget effect $\left(\mathrm{C}_{0}\right)$, sill $\left(\mathrm{C}_{0}+\mathrm{C}\right)$, range $(A)$, coefficient of determination $\left(\mathrm{R}^{2}\right)$ and spatial dependence (SD) for the semivariogram models tested (exponential, spherical and gaussian) for flow rate

\begin{tabular}{lcccccc}
\hline Month & Model & $\mathbf{C}_{\mathbf{0}}$ & $\mathbf{C}_{\mathbf{0}}+\mathbf{C}$ & $\mathbf{A}(\mathbf{m})$ & $\mathbf{R}^{\mathbf{2}}$ & $\mathbf{G D}=\left(\mathbf{C}_{\mathbf{0}} / \mathbf{C}_{\mathbf{0}}+\mathbf{C}\right)(\boldsymbol{\%})$ \\
\hline February & Exponential & 0.1 & 95.7 & 43.8 & 0.88 & 0.10 \\
& Spherical & 0.1 & 85.8 & 27.2 & 0.91 & 0.12 \\
& Gaussian & 10.7 & 86.4 & 23.4 & 0.90 & 12.38 \\
\multirow{3}{*}{ March } & Exponential & 0.1 & 87.6 & 43.2 & 0.87 & 0.11 \\
& Spherical & 0.1 & 79.1 & 27.5 & 0.91 & 0.13 \\
& Gaussian & 12.4 & 80.0 & 24.6 & 0.90 & 15.5 \\
\hline
\end{tabular}

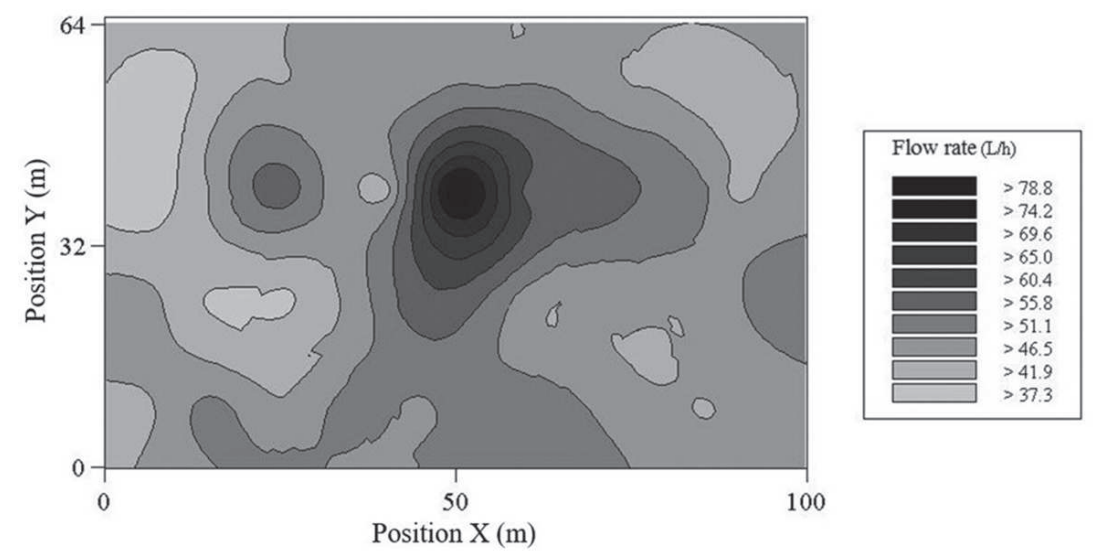

Figure 1: Spatial distribution of flow rates $\left(\mathrm{L} \mathrm{h}^{-1}\right)$ measured in February 2012. Source: Torres (2012).

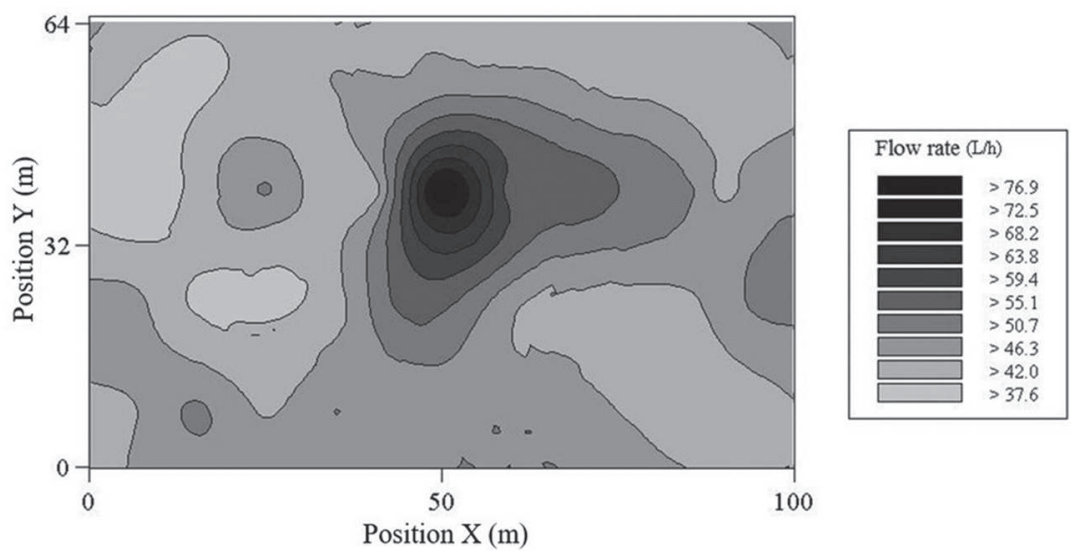

Figure 2: Spatial distribution of flow rates $\left(\mathrm{L} \mathrm{h}^{-1}\right)$ measured in March 2012. Source: Torres (2012). 
Table 6 describes the results of Kolmogorov-Smirnov and Shapiro-Wilk normality tests for AWC, with the Shapiro-Wilk test being the most recommended because the sample has less than 50 observations (Maroco, 2007). The results indicated that data are normal, which contributes positively to the geostatistical analysis to be performed more accurately and with possibility of expressing better results.

The results of the geostatistical analysis for AWC (mm) are presented in Table 7. Using the scale of spatial dependence by Cambardella et al. (1994), it was found that for the semivariograms obtained, the three models (exponential, spherical and Gaussian) showed strong spatial dependence: the nugget effects $\left(\mathrm{C}_{0}\right)$ were less than
$25 \%$ of the sill (GD $<25 \%$ ), with the exponential model having the highest dependence. However, analyzing both the coefficients of determination $\left(\mathrm{R}^{2}\right)$ of the models and the degree of spatial dependence (SD), at the same time, the spherical model stood out from the others. The $\mathrm{R}^{2}$ values obtained in this study were similar to those found by Lima et al. (2006), who reported $\mathrm{R}^{2}$ of 0.47 for AWC (mm), also for a Cambisol.

The $\mathrm{SD}$ and $\mathrm{R}^{2}$ values of this study corroborate several other authors' fidings, including Lemos Filho et al. (2008), Campos et al. (2013), Araújo et al. (2014) and Negreiros Neto et al. (2015), indicating the exponential and spherical models as being the most appropriate to fit the soil physical and hydraulic properties.

Table 4: Descriptive statistics for the variables sand, silt and clay (\%), bulk density $\left(\mathrm{d}_{\mathrm{s}}\right)$ and particle density $\left(\mathrm{d}_{\mathrm{p}}\right)$

\begin{tabular}{|c|c|c|c|c|c|c|}
\hline \multirow{2}{*}{$\frac{\text { Layer }}{(\mathrm{m})}$} & & Sand & Silt & Clay & \multirow{2}{*}{$\frac{d_{s}}{\left(\mathrm{~g} \mathrm{~cm}^{-3}\right)}$} & \multirow{2}{*}{$\begin{array}{c}d_{p} \\
\left(\mathrm{~g} \mathrm{~cm}^{-3}\right)\end{array}$} \\
\hline & & \multicolumn{3}{|c|}{$(\%)$} & & \\
\hline \multirow[t]{10}{*}{$0-0.3$} & $\mu$ & 72.38 & 4.75 & 22.87 & 1.64 & 2.60 \\
\hline & $\eta$ & 73.04 & 4.52 & 22.16 & 1.63 & 2.60 \\
\hline & $\sigma$ & 5.75 & 1.15 & 5.81 & 0.09 & 0.033 \\
\hline & $\sigma^{2}$ & 33.11 & 1.32 & 33.75 & 0.01 & 0.001 \\
\hline & $\mathrm{CV}$ & 7.95 & 24.23 & 25.40 & 5.44 & 1.27 \\
\hline & $\mathrm{V}_{\max }$ & 83.26 & 9.03 & 41.73 & 1.96 & 2.69 \\
\hline & $\mathrm{V}_{\text {mín }}$ & 53.88 & 3.34 & 12.51 & 1.50 & 2.55 \\
\hline & Kur & 1.58 & 6.43 & 1.60 & 3.53 & -0.31 \\
\hline & Ske & -0.72 & 2.20 & 0.83 & 1.46 & 0.46 \\
\hline & $\mathrm{N}$ & 40.00 & 40.00 & 40.00 & 40.00 & 40.00 \\
\hline
\end{tabular}

Mean $(\mu)$, median $(\eta)$, maximum and minimum value $\left(\mathrm{V}_{\max }\right.$ and $\left.\mathrm{V}_{\text {min }}\right)$, standard deviation $(\sigma)$, variance $\left(\sigma^{2}\right)$, coefficient of variation $(\mathrm{CV})$, skewness (Ass), kurtosis (Cur) and total sample number (n) for the contents of sand, silt and clay (\%), bulk density ( $\mathrm{d}_{\mathrm{s}}$ ), and particle density $\left(d_{p}\right)$.

Table 5: Descriptive statistics for the variables soil moisture at field capacity $\left(\theta_{\mathrm{Fc}}\right)$, permanent wilting point $\left(\theta_{\mathrm{PWP}}\right)$, and soil available water capacity (AWC)

\begin{tabular}{|c|c|c|c|c|}
\hline \multirow{2}{*}{$\begin{array}{l}\text { Layer } \\
(\mathrm{m}) \\
\end{array}$} & & $\boldsymbol{\theta}_{\mathrm{cc}}$ & $\boldsymbol{\theta}_{\mathrm{pmp}}$ & \multirow{2}{*}{$\begin{array}{l}\text { CAD } \\
(\mathrm{mm})\end{array}$} \\
\hline & & \multicolumn{2}{|c|}{$\left(\mathrm{cm}^{3} \mathrm{~cm}^{-3}\right)$} & \\
\hline & $\mu$ & 0.226 & 0.102 & 74.29 \\
\hline & $\eta$ & 0.226 & 0.100 & 75.37 \\
\hline & $\sigma$ & 0.042 & 0.023 & 13.21 \\
\hline & $\sigma^{2}$ & 0.002 & 0.001 & 174.42 \\
\hline \multirow[t]{6}{*}{$0-0.3$} & $\mathrm{CV}$ & 18.561 & 22.660 & 17.78 \\
\hline & $\mathrm{V}_{\max }$ & 0.298 & 0.157 & 104.55 \\
\hline & $\mathrm{V}_{\text {min }}$ & 0.130 & 0.056 & 42.42 \\
\hline & Kur & -0.539 & -0.544 & 0.36 \\
\hline & Ske & -0.335 & 0.009 & -0.17 \\
\hline & $\mathrm{n}$ & 40 & 40 & 40 \\
\hline
\end{tabular}

Table 6: Kolmogorov-Smirnov and Shapiro-Wilk normality tests for soil available water capacity (AWC), mm

\begin{tabular}{lccccccc}
\hline \multirow{2}{*}{ Profile $(\mathbf{m})$} & \multicolumn{3}{c}{ Kolmogorov-Smirnov } & & \multicolumn{3}{c}{ Shapiro-Wilk } \\
\cline { 2 - 3 } & p-value & p-lilliefors & K-S & & p-value & W \\
\hline $0-0.3$ & 0.2 & 0.2 & & $0.073^{*}$ & & 0.971 & $0.990^{*}$ \\
\hline
\end{tabular}

* Significant at $5 \%(\alpha=0,05)$

Rev. Ceres, Viçosa, v. 63, n.6, p. 782-788, nov/dez, 2016 
Table 7: Nugget effect $\left(\mathrm{C}_{0}\right)$, sill $\left(\mathrm{C}_{0}+\mathrm{C}\right)$, range $(A)$, coefficient of determination $\left(\mathrm{R}^{2}\right)$ and spatial dependence $(\mathrm{SD})$ for the semivariogram models tested (exponential, spherical and Gaussian)

\begin{tabular}{lccccc}
\hline Model & $\mathbf{C}_{\mathbf{0}}$ & $\mathbf{C}_{\mathbf{0}}+\mathbf{C}$ & $\mathbf{A}(\mathbf{m})$ & $\mathbf{R}^{\mathbf{2}}$ & $\mathbf{S D}=\left(\mathbf{C}_{\mathbf{0}} / \mathbf{C}_{\mathbf{0}}+\mathbf{C}\right)(\boldsymbol{\%})$ \\
\hline Exponential & 0.1 & 177.7 & 13.8 & 0.544 & 0.06 \\
Spherical & 5.7 & 178.2 & 12.2 & 0.622 & 3.2 \\
Gaussian & 24.6 & 178.0 & 9.87 & 0.621 & 13.82 \\
\hline
\end{tabular}

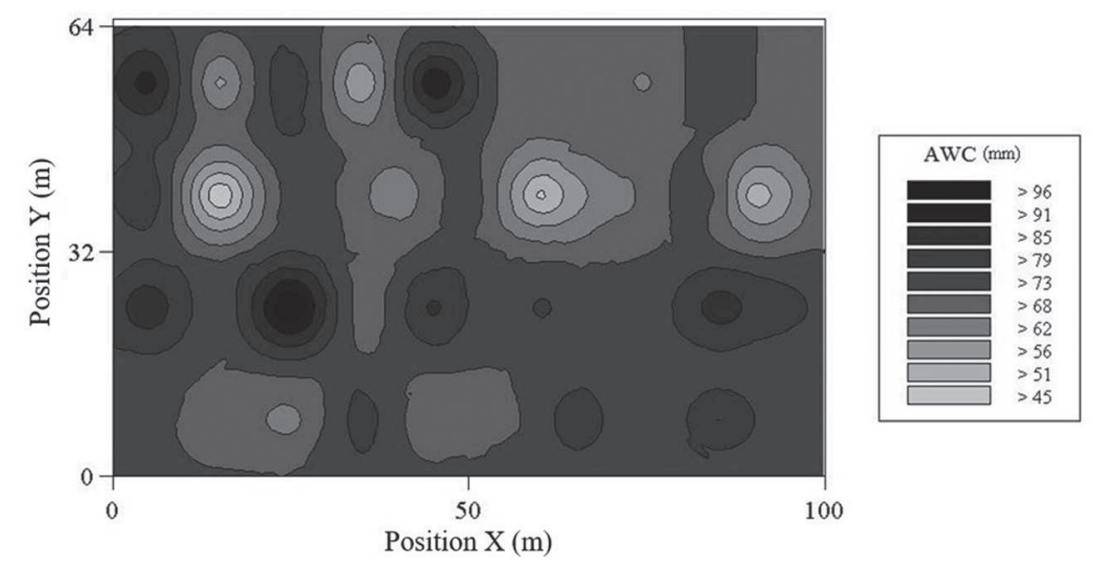

Figure 3: Spatial distribution of soil available water capacity (AWC) measured in the study area. Source: Torres (2012).

The kriging map of Figure 3 shows the spatial distribution of AWC (mm) in the soil profile depth of 0-0.3 $\mathrm{m}$. Note that AWC was highly variable and there was concentration of lower AWC values in the upper area and vice versa.

Areas that received more water through irrigation (higher flow rates) coincided precisely with areas that had lower available water capacity in the soil (AWC) and the reverse also happened, which shows a considerable spatial variability in the area of study and points out the need to manage irrigation in a spatially differentiated way, considering the non-homogeneity of the area.

\section{CONCLUSIONS}

The variogram analyses showed that the variables in study (flow rate and available water capacity in the soil) had strong spatial dependence, i.e., the geostatistical methods were suitable to describe their spatial variability. Although the irrigation system had relatively high Christiansen Uniformity Coefficients and Distribution Uniformity Coefficients, there was great spatial variability in the emitter flow rates in the area.

\section{AKNOWLEDGEMENTS}

The authors thank the National Council for Scientific and Technological Development (CNPq) for the assistance and financial support to this research (Processo No. 481399 /2010-0).

\section{REFERENCES}

Agostinho JMFS (2011) O aumento da rentabilidade do milho no Minho: eficiência do uso de água e redução dos custos associado à rega e à fertilização. Revista de Ciências Agrárias, 34:24-41.

Araújo DR, Mion RL, Sombra WA, Andrade RR \& Amorim MK (2014) Variabilidade espacial de atributos físicos em solo submetido à diferentes tipos de uso e manejo. Revista Caatinga, 27:101-115.

Bernardo S, Soares AA \& Mantovani EC (2011) Manual de Irrigação. $8^{\mathrm{a}}$ ed. Viçosa, Editora UFV. 625p.

Bralts VF \& Kesner CD (1983) Drip irrigation fiel uniformity estimation. Transactions of the ASAE, 26:1369-1374.

Cambardella CA, Moorman TB, Novak JM, Parkin TB, Karlen DL, Turco RF \& Konopka AE (1994) Field scale variability of soil properties in central Iowa soils. Journal Soil Science Society of America, 58:1501-1511.

Campos MCC, Oliveira IA, Aquino RE, Bergamin AC \& Silva DAP (2013) Distribuição espacial de atributos físicos do solo em área cultivada com cana-de-açúcar. Revista Agroambiente, 7:119-128.

Carmo Filho F, Espínola Sobrinho J \& Maia Neto JM (1991) Dados climatológicos de Mossoró: Um município semi-árido nordestino. Mossoró, ESAM. 121p. (Coleção Mossoroense, série C, 30).

Christiansen EJ (1942) Irrigation by sprinkler. Berkeley, University of California. 1.142p. (Bulletin, 670).

Coelho EF, Coelho Filho MA \& Oliveira SL (2005) Agricultura irrigada: eficiência de irrigação e de uso de água. Bahia Agrícola, $7: 57-60$.

Cunha FF, Pordeus RV, Maracajá PB, Freitas RS \& Mesquita LX (2008) Manejo de micro-irrigação baseado em avaliação do sistema na cultura do meloeiro. Revista Caatinga, 21:147-155. 
Donagema GK, Campos DVB, Calderano SB, Teixeira WG \& Viana JHM (2011) Manual de métodos de análise de solos. $2^{\mathrm{a}}$ ed. Rio de Janeiro, Embrapa Solos. 230p. (Documentos, 132).

Dourado Neto D, Nielsen DR, Hopmans JW, Reichardt K, Bacchi OOS \& Lopes PP (2001) Programa para confecção da curva de retenção de água no solo, modelo van Genuchten: soil water retention curve, SWRC (version 3,00 beta). Piracicaba, USP. CD-ROM

Embrapa - Empresa Brasileira de Pesquisa Agropecuária (2006) Centro Nacional de Pesquisa de Solos Sistema Brasileiro de Classificação de Solos. Rio de Janeiro, Embrapa Solos. $2^{a}$ ed. 306p.

Frizzone JA, Roberto R, Antonio CAG \& Celso HJ (2007) Produtividade do feijoeiro sob diferentes uniformidades de distribuição de água na superfície e na subsuperfície do solo. Engenharia Agrícola, 27:414-425.

Gamma Design Software (2004) GS+: Geostatistics for the Environmental Sciences. Plainwell, Gamma Design Software. CD-ROM.

Keller J \& Karmeli D (1975) Trickle irrigation design. Glendora, Rain bird Sprinkler Manufacturing Corporation. 133p.

Lemos Filho LCA (2010) Estabilidade temporal e análise espacial do armazenamento de água em solo arenoso da região de Petrolina-PE. Tese de Doutorado. Universidade Federal de Lavras, Lavras. $151 \mathrm{p}$

Lemos Filho LCA, Oliveira EL, Faria MA \& Andrade LAB (2008) Variação espacial da densidade do solo e matéria orgânica em uma área cultivada com cana-de-açúcar (Saccharum officinarum L.). Revista Ciência Agronômica, 39:193-202.

Lima FV, Silvino GS, Melo RSS, Lira EC \& Ribeiro TS (2015) Variabilidade espacial de atributos físicos do solo em área de encosta sob processo de degradação. Revista Caatinga, 28:5363.

Lima JAG, Mendes MAS, Duda GP \& Ferreira CV (2006) Variabilidade espacial de características físico-hídricas de um cambissolo cultivado com mamão no semi-árido do RN. Revista Caatinga 19:192-199.

Mantovani EC (2000) A irrigação do cafeeiro. ITEM: Irrigação e Tecnologia Moderna, 48:45-49.

Maroco J (2007) Análise Estatística com utilização do SPSS. $3^{\text {a }}$ ed. Lisboa, Edições Silabo Ltda. 824p.

Merriam JL \& Keller J (1978) Farm irrigation system evaluation a guide for management. Logan, Utah State University. 271p.
Negreiros Neto JV, Santos AC, Guarnieri A, Souza DJAT, Daronch DJ, Dotto MA \& Araújo AS (2014) Variabilidade espacial de atributos físico-químicos de um Latossolo Vermelho-Amarelo distrófico em sistema plantio direto. Semina: Ciências Agrárias, 35:193-204.

Nielsen DR, Biggar JW \& Erh RT (1973) Spatial variability of field-measured soil water properties. Hilgardia, 42:215-260.

Oliveira HFE, Colombo A, Faria LC \& Prado G (2012) Efeitos da velocidade e da direção do vento na uniformidade de aplicação de água de sistemas autopropelidos. Engenharia Agrícola, 32:669678.

Pereira GM (2001) Irrigação por aspersão convencional. Lavras, UFLA/FAEPE. 79p

Prado G \& Colombo A (2011) Ajuste de parâmetros para distorção da distribuição de água aplicada por canhões hidráulicos em condições de vento. Irriga, 16:52-69.

Ribeiro Júnior PJ \& Diggle PJ (2001) GeoR: a package for geostatistical analysis. R-NEWS, 1:15-18.

Santos FL, Correia MM, Coelho RR, Sousa A, Paço TA \& Pereira LS (2013) Efeitos da rega e do regime hídrico em olival super intensivo no Alentejo. Revista de Ciências Agrárias, 36:206219.

Torres MM (2012) Análise espacial e estabilidade temporal do armazenamento de água em cambissolo da região do Vale do Açu, RN. Dissertação de Mestrado. Universidade Federal Rural do Semi-Árido, Mossoró. 87p.

Van Genuchten MT (1980) A closed-form equation for predicting the hydraulic conductivity of unsaturated soils. Journal Soil Science Society of America, 44:892-898.

Vian AL, Santi AL, Amado TJC, Cherubin MR, Simon DH, Damian JM \& Bredemeier C (2016) Variabilidade espacial da produtividade de milho irrigado e sua correlação com variáveis explicativas de planta. Ciência Rural, 46:464-471.

Vieira SR (2000) Geoestatística em estudos de variabilidade espacial do solo. In: Novais RF, Alvarez VH \& Schaefer CEGR (Eds.) Tópicos em ciência do solo. Viçosa, Sociedade Brasileira de Ciência do Solo. p.01-54.

Warrick AW \& Nielsen DR (1980) Spatial variability of soil physical properties in the field. In: Hillel D (Ed.) Applications of Soil Physics. New York, Academic. p.319-344.

Wilding LP \& Drees LR (1983) Variabilidade espacial e pedologia. In: Liquidação LP, Smeck NE \& Hall GF (Eds.) Pedogênese e taxonomia de solo: I. Conceitos e interações. New York, Elsevier. p.83-116. 